OPEN ACCESS

Edited by:

Paul E. Renaud,

Akvaplan-niva, Norway

Reviewed by:

Tobias Tamelander,

University of Helsinki, Finland

Kalle Olli,

University of Tartu, Estonia

${ }^{*}$ Correspondence:

Susana Agusti

susana.agusti@kaust.edu.sa

Specialty section:

This article was submitted to Global Change and the Future Ocean,

a section of the journal

Frontiers in Marine Science

Received: 05 October 2017 Accepted: 14 December 2017 Published: 22 December 2017

Citation:

Agusti S, Martinez-Ayala J, Regaudie-de-Gioux A and Duarte CM

(2017) Oligotrophication and Metabolic Slowing-Down of a NW Mediterranean Coastal Ecosystem.

Front. Mar. Sci. 4:432

doi: 10.3389/fmars.2017.00432

\section{Oligotrophication and Metabolic Slowing-Down of a NW Mediterranean Coastal Ecosystem}

\author{
Susana Agusti ${ }^{1 *}$, Juan Martinez-Ayala ${ }^{1}$, Aurore Regaudie-de-Gioux ${ }^{2}$ and \\ Carlos M. Duarte ${ }^{1}$ \\ ${ }^{1}$ Red Sea Research Center, King Abdullah University of Science and Technology, Thuwal, Saudi Arabia, ${ }^{2}$ Instituto \\ Mediterráneo de Estudios Avanzados (IMEDEA), CSIC-UIB, Mallorca, Spain
}

Increased oligotrophication is expected for oligotrophic areas as a consequence of ocean warming, which reduces diffusive vertical nutrient supply due to strengthened stratification. Evidence of ocean oligotrophication has been, thus far, reported for the open ocean. Here we reported oligotrophication and associated changes in plankton community metabolism with warming in a pristine, oligotrophic Mediterranean coastal area (Cap Salines, Mallorca Island, Spain) during a 10 years time series. As a temperate area, there were seasonal patterns associated to changes in the broad temperature range $\left(12.0-28.4^{\circ} \mathrm{C}\right)$, with a primary phytoplankton bloom in late winter and a secondary one in the fall. Community respiration $(R)$ rates peaked during summers and showed higher rates relative to gross primary production (GPP) with a prevalence of heterotrophic metabolism (2/3's of net community production (NCP) estimates). Chlorophyll a concentration significantly decreased with increasing water temperature in the coastal site at a rate of $0.014 \pm 0.003 \mu \mathrm{g}$ Chla $\mathrm{L}^{-1}{ }^{\circ} \mathrm{C}^{-1}(P<0.0001)$. The study revealed a significant decrease with time in Chlorophyll a concentration and nutrients concentration, indicating oligotrophication during the last decade. Community productivity consistently decreased with time as both GPP and R showed a significant decline. Warming of the Mediterranean Sea is expected to increase plankton metabolic rates, but the results indicated that the associated oligotrophication must lead to a slowing down of the community metabolism.

Keywords: oligotrophiocation, mediterranean sea, respiration, net community production, nutrients, gross primary production, warming, chlorophyll

\section{INTRODUCTION}

Evidence of recent oligotrophication of the ocean, reflected in decreased chlorophyll a concentration (Antoine et al., 2005; O'Malley et al., 2009; Boyce et al., 2010; Gregg and Rousseaux, 2014; Signorini et al., 2015), reduced primary production (Behrenfeld et al., 2006; Signorini et al., 2015), and an expansion of the area occupied by the subtropical gyres (McClain et al., 2004; Polovina et al., 2008; Irwin and Oliver, 2009; Signorini et al., 2015) has raised interest on the drivers of this process. Ocean oligotrophication is believed to be driven by ocean warming, which reduces diffusive vertical nutrient supply due to strengthened stratification (Sarmiento et al., 2004; Signorini et al., 2015), and leads to reduced primary production and biomass with an expected imbalance on 
net community metabolism, as respiration rates will exceed primary production (Harris et al., 2006; López-Urrutia et al., 2006; Regaudie-de-Gioux and Duarte, 2012; Garcia-Corral et al., 2014, 2017).

However, to-date, evidence of marine oligotrophication is largely restricted to the open-ocean, with many areas of the coastal ocean exhibiting an opposite eutrophication pattern, due to increased nutrient inputs (Duarte, 2014; Paerl et al., 2014) together with disruption of food webs (Cloern et al., 2016; Östman et al., 2016). A summary of long-term changes in coastal phytoplankton communities reported a prevalence of eutrophication trends, with oligotrophication observed only in 22 of the ecosystems studied (Zingone et al., 2010). Mozetic et al. (2010) reported oligotrophication of the Northern Adriactic Sea involving a decline of chlorophyll a concentration of, on average, about $-0.11 \mathrm{mg} \mathrm{m}^{-3}$ year $^{-1}$ along the period 1970 2007 attributed to reduced nutrient input from the Po river. Nishikawa et al. (2010) reported oligotrophication of the Eastern Seto Inland Sea, which they attributed to reduced nutrient inputs and warming resulting in increased stratification and reduced nutrient supply.

Here we report oligotrophication and associated changes in plankton community metabolism with warming in a pristine, oligotrophic Mediterranean coastal area (Cap Salines, Mallorca Island, Spain). We do so based on a 10 years time series of chlorophyll and plankton community metabolism at this coastal site.

\section{METHODS}

The study was conducted at the Cap Salines $\left(39.2653^{\circ} \mathrm{N}, 3.0538^{\circ}\right.$ E), adjacent to the Cap Salines Light House field station of the Spanish Council for Scientific Research. This facility is located in a protected, pristine coastal area away from any direct human influences, as is characterized by very transparent and oligotrophic waters, advected from Mediterranean open waters through a dominant western current.

Surface $(1 \mathrm{~m})$ seawater samples (upper mixed layer) were collected fortnightly between 17 January 2006 and 19 February 2015. Temperature was measured using a highprecision calibrated thermometer (ACCD650P Handheld Pt100 Thermometer). Total chlorophyll $a$ concentration, Chl $a$, was determined fluorometrically (Parsons et al., 1984) from the cells of a $150 \mathrm{~mL}$ water sample retained on a GF/F filter, and extracting Chl $a$ for $24 \mathrm{~h}$ with $90 \%$ acetone before measuring fluorescence of a non-acidification module in a Trilogy fluorometer calibrated with pure chlorophyll $a$. Samples for dissolved inorganic nutrient concentrations were kept frozen until analyzed using standard methods (Hansen and Koroleff, 1999) in a Bran Luebe AA3 autoanalyzer.

Planktonic metabolism was evaluated monthly from changes in dissolved oxygen concentrations along $24 \mathrm{~h}$ incubations (Carpenter, 1965), which were determined by automated highprecision Winkler titration with a potentiometric end- point Metrohm 808 Titrando (Oudot et al., 1988). A total of 21 Winkler bottles were carefully filled, by siphoning water and allowing it to overflow, with freshly collected surface seawater. Seven of the bottles were immediately fixed to represent the initial oxygen concentration, and the other 14, seven transparent and seven black borosilicate glass bottles were incubated for $24 \mathrm{~h}$ under natural solar radiation in a 75-1 tank equipped with a cooling and heating system (Titan 1000 Chiller and Aquatic Nature micro Proccesor- 300W) set to ambient seawater temperature $\left( \pm 1^{\circ} \mathrm{C}\right)$. Oxygen was fixed in the incubated bottles at the end of the $24 \mathrm{~h}$ incubation period and titrated to determine oxygen concentration. Net community metabolism (NCP, $\mu$ mol $\mathrm{O}_{2}$ $\mathrm{L}^{-1} \mathrm{day}^{-1}$ ) was calculated from the difference between the oxygen concentration at the end of the $24 \mathrm{~h}$ in the transparent borosilicate glass bottles incubation period and the initial oxygen concentration; community respiration rates $\left(\mathrm{CR}, \mu \mathrm{mol} \mathrm{O}_{2} \mathrm{~L}^{-1}\right.$ $\mathrm{day}^{-1}$ ) were determined from the difference between the oxygen concentration at the end of the $24 \mathrm{~h}$ incubation period in the dark borosilicate glass bottles and the initial oxygen concentration; and gross primary production (GPP, $\mu \mathrm{mol} \mathrm{O}_{2} \mathrm{~L}^{-1}$ day $^{-1}$ ) was calculated as NCP + CR.

The temperature response of plankton communities was described by fitting, using least squares regression analysis, the Arrhenius equation:

$$
L n Y=A \exp ^{-\mathrm{AE} / \mathrm{kT}}
$$

where $\mathrm{Y}$ is the property of interest, $\mathrm{AE}$ is the activation energy $(\mathrm{eV}), \mathrm{k}$ is the Boltzmann' s constant (8.617734 $\left.10^{-5} \mathrm{eV} \mathrm{K} \mathrm{K}^{-1}\right)$ and $\mathrm{T}$ is the sea-surface water temperature $\left({ }^{\circ} \mathrm{K}\right)$, and $\mathrm{A}$ is a fitted intercept.

\section{RESULTS}

The Cap Salines pelagic ecosystem was characterized by oligotrophic conditions, as reflected in low mean surface chlorophyll a concentration and dissolved inorganic nutrient concentrations (Table 1). The plankton community was characterized by higher respiration rate relative to GPP and, hence, a prevalence of heterotrophic metabolism (2/3's of NCP estimates $<0$, Table 1 ).

The community experienced pronounced seasonal changes with broad ranges in temperature (from 12.0 to $28.4^{\circ} \mathrm{C}$ ) and nutrient concentrations, resulting in a primary phytoplankton bloom in late winter and a secondary one in the fall, as well as increased respiration rates during summer (Figure 1). There was a trend for the community studied to become more oligotrophic with increasing temperature, as reflected in a decline in Chl $a$ with temperature at a rate of $0.014 \pm 0.003 \mu \mathrm{g}$ Chla $\mathrm{L}^{-1}{ }^{\circ} \mathrm{C}^{-1}\left(R^{2}=0.11, P<0.0001\right)$, corresponding to an activation energy for thermal decline of $-0.38 \pm 0.06 \mathrm{eV}$ (Figure 2). Community respiration rates (R) and GPP increased with increasing temperature, with a higher activation energy for $\mathrm{R}(0.68 \pm 0.15 \mathrm{eV}, P<0.0001)$ compared to GPP $(0.45 \pm 0.17 \mathrm{eV}$, $P=0.013$, Figure 2). Both rates, when normalized per unit of Chl $a$, also increased significantly with increasing temperature ( $P<0.001$ and $P=0.028$ for R and GPP, respectively). This temperature-dependent metabolic increase results in increased metabolic rates in summer, despite low biomass in this period (Figure 1). 
TABLE 1 | Mean \pm SE, minimum, and maximum sea surface temperature, nutrient concentration, chlorophyll a concentration, gross primary production, community respiration, net community production, and the linear rates of change ( $\pm \mathrm{SE})$, along with the $R^{2}$ and probability of the observed linear trends, in Cap Salines coastal waters along the observation period (2006-2015).

\begin{tabular}{|c|c|c|c|}
\hline Property & Mean $\pm \mathrm{SE}, \min -\max (\mathrm{N})$ & $\begin{array}{l}\text { Trend }( \pm \text { SE) } \\
\left(\text { year }^{-1}\right)\end{array}$ & $R^{2}(P)$ \\
\hline Sea surface temperature $\left({ }^{\circ} \mathrm{C}\right)$ & $20.1 \pm 0.3,12-28.4(184)$ & - & - \\
\hline $\mathrm{PO}_{4}(\mu \mathrm{mol} \mathrm{L}-1)$ & $0.15 \pm 0.02, \mathrm{BDL}-2.6(173)$ & - & - \\
\hline $\mathrm{NO}_{x}\left(\mu \mathrm{mol} \mathrm{L}{ }^{-1}\right)$ & $0.56 \pm 0.06, \mathrm{BDL}-6.51(174)$ & $-0.059 \pm 0.022$ & $0.04(0.007)$ \\
\hline $\mathrm{NH}_{4}\left(\mu \mathrm{mol} \mathrm{L}{ }^{-1}\right)$ & $0.61 \pm 0.09, \mathrm{BDL}-9.1(131)$ & - & - \\
\hline $\operatorname{GPP}\left(\mu \mathrm{mol} \mathrm{O}_{2} \mathrm{~L}^{-1}\right.$ day $\left.^{-1}\right)$ & $2.05 \pm 0.15,0.02-7.82(88)$ & $-0.24 \pm 0.05$ & $0.20(<0.0001)$ \\
\hline $\mathrm{CR}\left(\mu \mathrm{mol} \mathrm{O}_{2} \mathrm{~L}^{-1}\right.$ day $\left.^{-1}\right)$ & $3.28 \pm 0.33,0.05-19.3(88)$ & $-0.44 \pm 0.11$ & $0.15(<0.0001)$ \\
\hline $\mathrm{NCP}\left(\mu \mathrm{mol} \mathrm{O} \mathrm{L}_{2} \mathrm{~L}^{-1}\right.$ day $\left.^{-1}\right)$ & $-1.25 \pm 0.25,-12.7-3.08(97)$ & - & - \\
\hline
\end{tabular}

$N$, number of observations; $B D L$, below detection limit. -, not significant $(P>0.05)$.

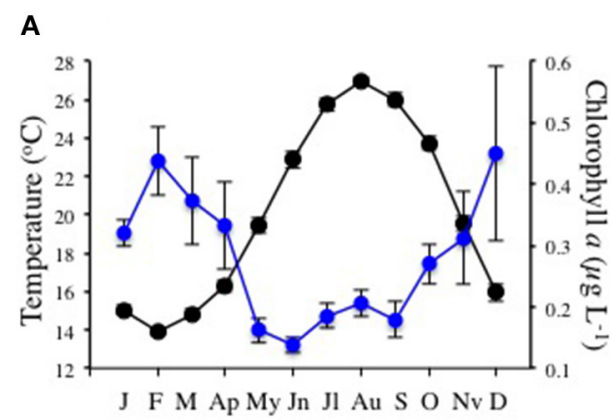

B

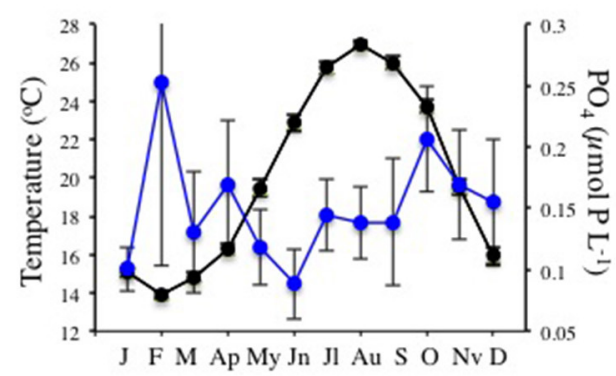

C

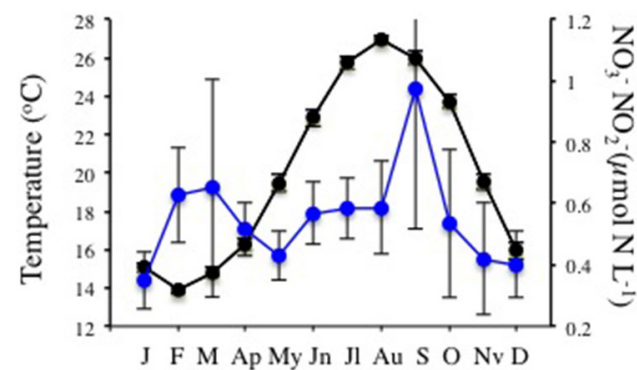

Month
D

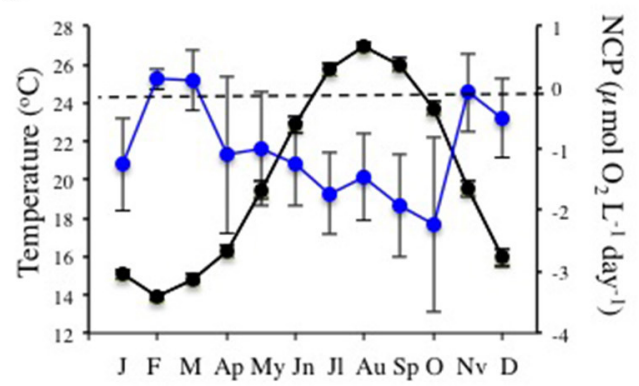

E

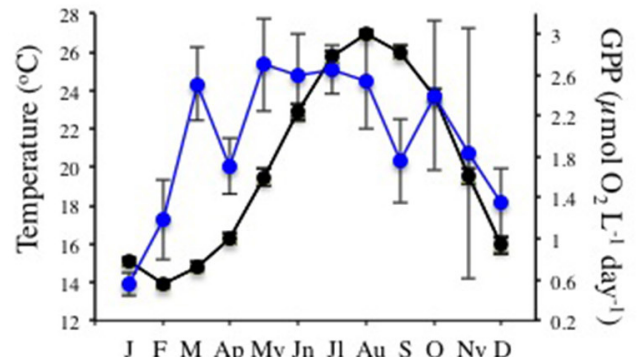

$\mathbf{F}$

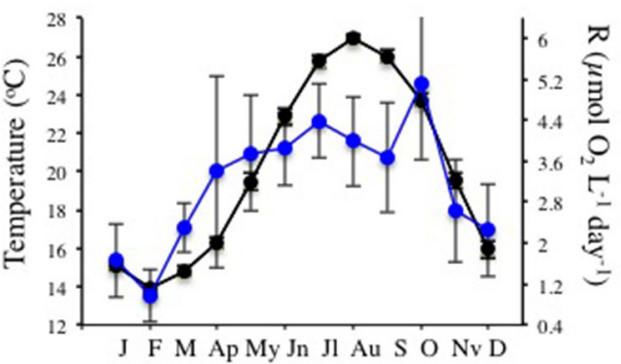

Month

FIGURE 1 | Mean ( \pm SE) monthly sea surface temperature (black dots and continuous lines) and (A) chlorophyll a concentration, (B) phosphate concentration, (C) nitrate + nitrite concentration, (D) net community production (NCP), (E) gross primary production (GPP), and (F) community respiration (R), in Cap Salines coastal waters (Mediterranean Sea) along the observation period (January 2006 -December 2015). The bars encompassed the SE. The dotted line in plot (D) marks balanced NCP. 
Chlorophyll a concentration showed a significant $(P=$ 0.025, Table 1) decline along the sampling period, paralleled by a decline in GPP and a particularly steep decline in community respiration rates (Figure 3, Table 1). This decline was accompanied by a significant decline in the concentration of nitrate and nitrite along the sampling period (Figure 3, Table 1).

\section{DISCUSSION}

The plankton community at Cap Ses Salines showed a seasonal pattern characteristic of the Mediterranean coastal zone, characterized by a late winter bloom followed by a secondary bloom in the fall, low chlorophyll a concentration and primary production in the summer along with high respiration rates (e.g., Duarte et al., 2004; Navarro et al., 2004). The prevalence of heterotrophic metabolism is consistent with the oligotrophic nature of this ecosystem (Duarte and Agustí, 1998; Duarte and Regaudie-de-Gioux, 2009; Duarte et al., 2013) and showed a similar prevalence of heterotrophic communities as the open Mediterranean Sea (Regaudie-de-Gioux et al., 2009). Indeed, the average metabolic rates for the plankton community at Cap Salines were somewhat below but otherwise remarkably similar to those reported for plankton communities in the open Mediterranean Sea (mean \pm SE GPP $2.4 \pm 0.4 \mu$ mol $\mathrm{O}_{2} \mathrm{~L}^{-1}$ day $^{-1}$, CR 3.8 $\pm 0.5 \mu \mathrm{mol} \mathrm{O} \mathrm{L}^{-1} \mathrm{day}^{-1}$, and NCP averaged $-0.8 \pm 0.6 \mu \mathrm{mol} \mathrm{O} \mathrm{L}^{-1}$ day $^{-1}$, cf. Regaudie-de-Gioux et al., 2009).

The Cap Salines ecosystem underwent an oligotrophication trend throughout this decade-long study, as reflected in significant long-term trends toward declining nitrate and nitrite concentrations, as well as declining trends in chlorophyll a concentration. The decline in chlorophyll $a$ concentration represented a loss of $4.5 \%$ per year equivalent to $0.17 \mu \mathrm{g} \mathrm{Chl} \mathrm{L}^{-1}$ during the decade studied. The oligotrophication trend in this Mediterranean coastal ecosystem was associated with a slowingdown of metabolic rates, with both GPP and CR declining over time. Although the decline was somewhat faster for CR than for GPP, these differences were not significant, so that these changes balanced each resulting in no significant decline in NCP over time (Table 1).

The oligotrophication observed in Cap Salines during the study decade is representative of the dynamics of the upper mixed layer and is consistent with reports of oligotrophication across the oligotrophic ocean, as reflected in declining chlorophyll $a$ concentrations (Antoine et al., 2005; O’Malley et al., 2009; Boyce et al., 2010; Gregg and Rousseaux, 2014; Signorini et al., 2015), and a reported decline in chlorophyll $a$ concentration in the central Mediterranean Sea, associated with changes in circulation (Volpe et al., 2012). Oligotrophication of the surface ocean may be partially compensated by increased biomass and primary production at depth, which would not have been captured in the study, conducted at a shallow, vertically mixed layer. However, there is no clear evidence for such compensatory mechanisms for oligotrophication in the open ocean. Such oligotrophication of the oligotrophic ocean has been attributed to warming and

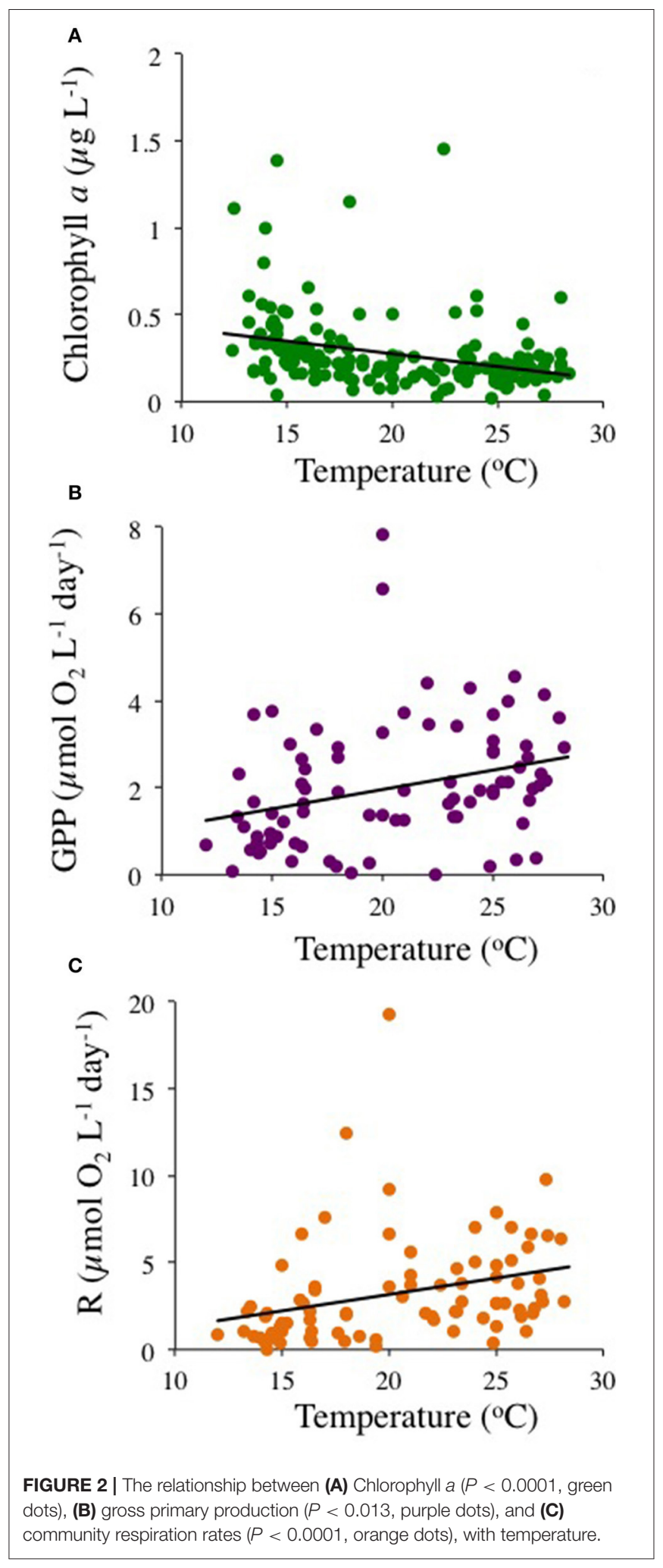

reduced nutrient inputs. We did indeed observe a decline in nitrate and nitrite concentration over time, which is likely to reflect oceanic, far-field effects, rather than local drivers, as there is no known point-source of nutrient inputs in the pristine area 

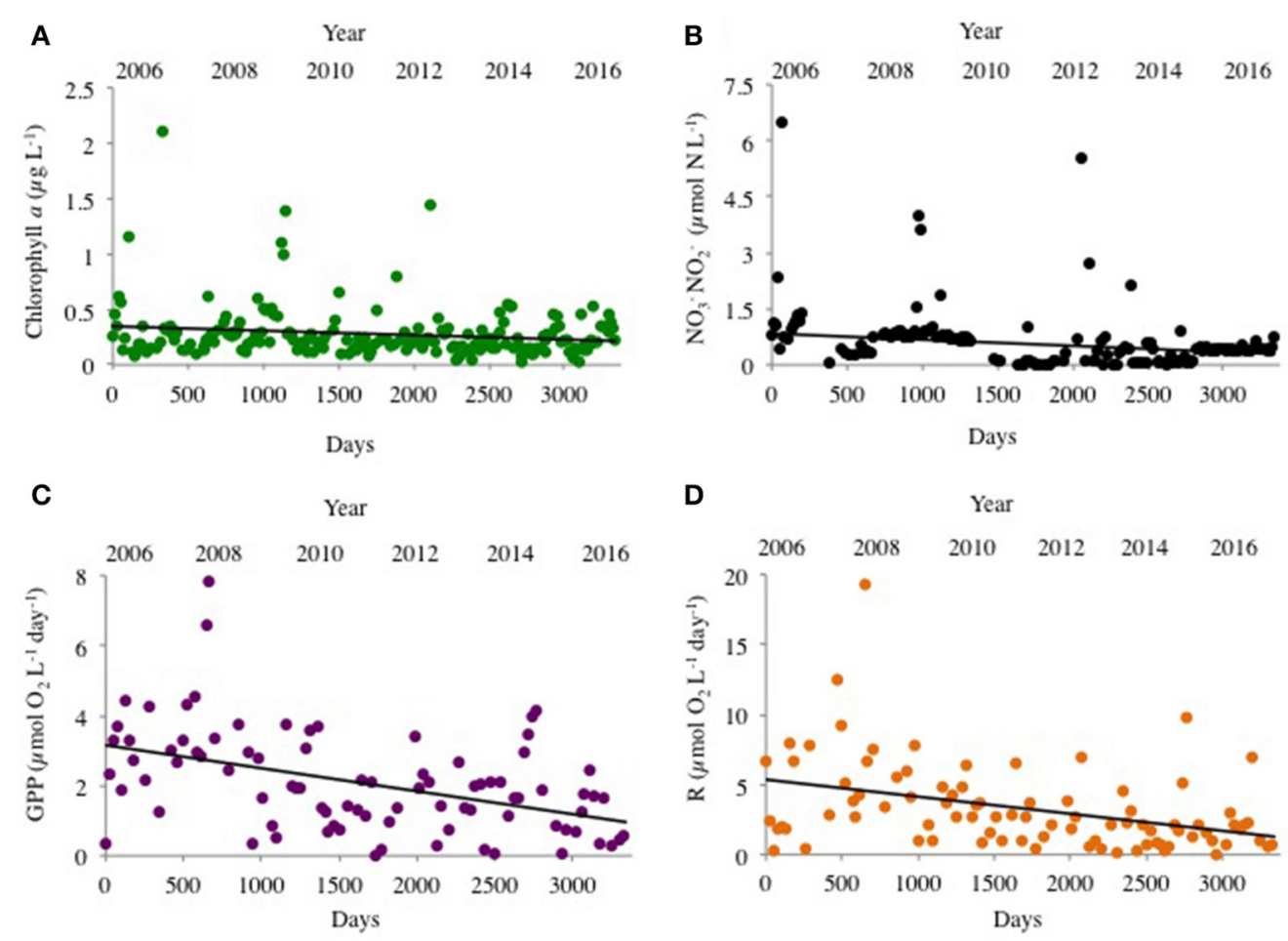

FIGURE 3 | Changes in (A) chlorophyll a concentration, (B) nutrients, (C) gross primary production, and (D) community respiration, with the increasing time in Cap Salines coastal waters along the observation period (2006-2015). Solid lines show significant fitted linear trends (cf. Table 1).

studied here. However, we did not observe a significant warming trend in these data, probably because elucidating these requires a long-term, $>20$ year, time series compared to the decade spanned by our analysis. Indeed, warming of the western Mediterranean basin has been shown, on a study encompassing three decades, to be proceeding at an average rate of $0.25^{\circ} \mathrm{C}$ decade ${ }^{-1}$, with important biological consequences (Marbà et al., 2015).

Chlorophyll a concentration declined with warming, with an $\mathrm{AE}$ of $-0.38 \pm 0.06 \mathrm{eV}$, confirming that the observed oligotrophication is consistent with warming of the Mediterranean. Our results also supported the prediction that plankton community metabolism increases with increasing temperature (Harris et al., 2006; López-Urrutia et al., 2006). Community respiration and GPP increased with increasing temperature, with a higher temperature-sensitivity, as reflected in the activation energy (AE), for $\mathrm{R}(\mathrm{AE} 0.68 \pm 0.15 \mathrm{eV}$ ) compared to GPP (AE $0.45 \pm 0.17 \mathrm{eV})$, consistent with theoretical arguments (Harris et al., 2006; López-Urrutia et al., 2006) and similar to the AE's of 0.66 and $0.32 \mathrm{eV}$ for CR and GPP, respectively, derived from a global meta-analysis of planktonic metabolic rates (Regaudie-de-Gioux and Duarte, 2012). GarciaCorral et al. (2014, 2017) report steeper AE's for community metabolism in the tropical and subtropical ocean. However, the AE's for community metabolism in the Mediterranean plankton community investigated here is well below the geometric mean $\mathrm{AE}$ of $1.58 \pm 0.48 \mathrm{eV}$ describing the biological responses to temperature of Mediterranean biota (Marbà et al., 2015). Indeed, whereas warming of the Mediterranean is expected to lead to increased plankton metabolic rates, oligotrophication led to a slowing down of community metabolism in the study area. Temperature increased the per biomass-specific metabolic rate, as reflected in the increase on $\mathrm{R}$ and GPP to Chl $a$ ratios with temperature. This helps explain the seasonal responses with higher rates in summer despite the decrease in biomass. But oligotrophication sets a limit to community biomass and, in consequence, to biological activity, including GPP, constrained by nutrient supply, and community respiration, itself dependent on organic carbon supplied by primary production.

The results presented here extend the oligotrophication trend affecting the subtropical and tropical ocean to oligotrophic waters in Cap Salines, and show that this oligotrophication is accompanied by a slowing down of surface plankton metabolic rates. Because the pelagic food web depends on plankton metabolism, the slowing down of plankton community metabolism with Mediterranean oligotrophication would have consequences cascading across the pelagic ecosystem.

\section{AUTHOR CONTRIBUTIONS}

SA and CD designed the study. SA, CD, JM-A and AR-d-G, contributed to the data acquisition and analysis. All authors contributed to write the paper. 


\section{ACKNOWLEDGMENTS}

This research is a contribution to the projects MEDEICG (ref. CTM2009-07013) and ESTRESX (ref. CTM201232603) funded by the Spanish Ministry of Economy and

\section{REFERENCES}

Antoine, D., Morel, A., Gordon, H. R., Banzon, V. F., and Evans, R. H. (2005). Bringing ocean color observations of the 1980s and 2000s in search of longterm trends. J. Geophys. Res. 110, 1-22. doi: 10.1029/2004JC002620

Behrenfeld, M. J., O’Malley, R. T., Siegel, D. A., McClain, C. R., Sarmiento, J. L., Feldman, G. C., et al. (2006). Climate-driven trends in contemporary ocean productivity. Nat. Lett. 444, 752-755. doi: 10.1038/nature05317

Boyce, D. G., Lewis, M. R., and Worm, B. (2010). Global phytoplankton decline over the past century. Nature 466, 591-596. doi: 10.1038/nature09268

Carpenter, J. H. (1965). The accuracy of the winkler method for dissolved oxygen analysis. Limnol. Oceanogr. 10, 135-140. doi: 10.4319/lo.1965.10.1.0135

Cloern, J. E., Abreu, P. C., Carstensen, J., Chauvaud, L., Elmgren, R., Grall, J., et al. (2016). Human activities and climate variability drive fast-paced change across the world's estuarine-coastal ecosystems. Glob. Chang. Biol. 22, 513-529. doi: $10.1111 /$ gcb.13059

Duarte, C. M. (2014). Global change and the future ocean: a grand challenge for marine sciences. Front. Mar. Sci. 1:63. doi: 10.3389/fmars.2014.00063

Duarte, C. M., and Agustí, S. (1998). The $\mathrm{CO}_{2}$ balance of unproductive aquatic ecosystems. Science 281, 234-236. doi: 10.1126/science.281.5374.234

Duarte, C. M., Agustí, S., and Vaqué, D. (2004). Controls on planktonic metabolism in the Bay of Blanes, north-western Mediterranean littoral. Limnol. Oceanogr. 49, 2162-2170. doi: 10.4319/lo.2004.49.6.2162

Duarte, C. M., and Regaudie-de-Gioux, A. (2009). Thresholds of gross primary production for the metabolic balance of marine planktonic communities. Limnol. Oceanogr. 54, 1015-1022. doi: 10.4319/lo.2009.54.3.1015

Duarte, C. M., Regaudie-de-Gioux, A., Arrieta, J. M., Delgado-Huertas, A., and Agustí, S. (2013). The oligotrophic ocean is heterotrophic. Ann. Rev. Mar. Sci. 5, 551-569. doi: 10.1146/annurev-marine-121211-172337

Garcia-Corral, L., Carrillo-de-Albornoz, P., Steckbauer, A., Pérez-Lorenzo, M., Navarro, N., Serret, P., et al. (2017). Temperature dependence of plankton community metabolism in the subtropical and tropical ocean. Glob. Biogeochem. Cycles 31, 1141-1154. doi: 10.1002/2017GB005629

Garcia-Corral, L. S., Barber, E., Regaudie-de-Gioux, A., Sal, S., Holding, J. M., Agust,í, S., et al. (2014). Temperature dependence of planktonic metabolism in the subtropical North Atlantic Ocean. Biogeosciences 11, 4529-4540. doi: 10.5194/bg-11-4529-2014

Gregg, W. W., and Rousseaux, C. S. (2014). Decadal trends in global pelagic ocean chlorophyll: a new assessment integrating multiple satellites, in situ data, and models. Geophys. Res. Oceans 119, 5921-5933. doi: 10.1002/2014JC 010158

Hansen, H. P., and Koroleff, F. (1999). “Determination of nutrients," in Methods of Seawater Analysis, eds K. Grasshoff, K. Kremling, and M. Ehrhardt (Weinheim: Wiley-VCH Verlag GmbH). doi: 10.1002/9783527613984.ch10

Harris, L. A., Duarte, C. M., and Nixon, S. W. (2006). Allometric laws and prediction in estuarine and coastal ecology. Estuaries Coasts 29, 343-347. doi: $10.1007 / \mathrm{BF} 02782002$

Irwin, A. J., and Oliver, M. J. (2009). Are ocean deserts getting larger? Geophys. Res. Lett. 36:L18609. doi: 10.1029/2009GL039883

López-Urrutia, Á., San Martin, E., Harris, R. P., and Irigoien, X. (2006). Scaling the metabolic balance of the oceans. Proc. Natl. Acad. Sci. U.S.A. 103, 8739-8744. doi: $10.1073 /$ pnas.0601137103

Marbà, N., Jordà, G., Agustí, S., Girard, C., and Duarte, C. M. (2015). Footprints of climate change on Mediterranean Sea biota. Front. Mar. Sci. 2:56. doi: 10.3389/fmars.2015.00056

McClain, C. R., Signorini, S. R., and Christian, J. R. (2004). Subtropical gyre variability observed by ocean-color satellites. Deep Sea Res. Part II Top. Stud. Oceanogr. 51, 281-301. doi: 10.1016/j.dsr2.2003.08.002

Mozetič, P., Solidoro, C., Cossarini, G., Socal, G., Precali, R., Francé, J., et al. (2010). Recent trends towards oligotrophication of the northern Adriatic:
Competitiveness, and also supported by the King Abdullah University of Science and Technology by S. Agusti's baseline funds. We thank J.C. Alonso, P. Carrillo de Albornoz, and N. Carrillo for help with sampling and analysis at the laboratory.

evidence from chlorophyll a time series. Estuaries Coasts 33, 362-375. doi: 10.1007/s12237-009-9191-7

Navarro, N., Agustí, S., and Duarte, C. M. (2004). Plankton metabolism and dissolved organic carbon use in the Bay of Palma, NW Mediterranean Sea. Aquat. Microb. Ecol. 37, 47-54. doi: 10.3354/ame037047

Nishikawa, T., Hori, Y., Nagai, S., Miyahara, K., Nakamura, Y., Harada, K., et al. (2010). Nutrient and phytoplankton dynamics in Harima-Nada, eastern Seto Inland Sea, Japan during a 35-year period from 1973 to 2007. Estuaries Coasts 33, 417-427. doi: 10.1007/s12237-009-9198-0

O'Malley, R. T., Behrenfeld, M. J., Siegel, D. A., and Maritorena, S. (2009). Global ocean phytoplankton in "State of the Climate in 2011". Bull. Amer. Meteorolog. Soc. 91, S75-S78.

Östman, Ö., Eklöf, J., Eriksson, B. K., Olsson, J., Moksnes, P. O., and Bergström, U. (2016). Top-down control as important as nutrient enrichment for eutrophication effects in North Atlantic coastal ecosystems. J. Applied Ecol. 53, 1138-1147. doi: 10.1111/1365-2664.12654

Oudot, C., Gerard, R., Morin, P., and Gningue, I. (1988). Precise shipboard determination of dissolved oxygen (Winkler Procedure) for productivity studies with a commercial system. Limnol. Oceanogr. 33, 146-150. doi: 10.4319/lo.1988.33.1.0146

Paerl, H. W., Hall, N. S., Peierls, B. L., and Rossignol, K. L. (2014). Evolving paradigms and challenges in estuarine and coastal eutrophication dynamics in a culturally and climatically stressed world. Estuaries Coasts 37, 243-258. doi: 10.1007/s12237-014-9773-x

Parsons, T. R., Maita, Y., and Lalli, C. M. (1984). A Manual of Chemical and Biological Methods for Seawater Analysis. Oxford: Pergamon Press.

Polovina, J. J., Howell, E. A., and Abecassis, M. (2008). Ocean's least productive waters are expanding. Geophys. Res. Lett. 35:L03618. doi: 10.1029/2007GL031745

Regaudie-de-Gioux, A., and and, C. M., Duarte (2012). Temperature dependence of planktonic metabolism in the ocean. Glob. Biogeochem. Cycles 26:GB1015. doi: 10.1029/2010GB003907

Regaudie-de-Gioux, A., Vaquer-Sunyer, R., and Duarte, C. M. (2009). Patterns in planktonic metabolism in the Mediterranean Sea. Biogeosciences 6, 3081-3089. doi: 10.5194/bg-6-3081-2009

Sarmiento, J. L., Slater, R., Barber, R., Bopp, L., Doney, S. C., Hirst, A. C., et al. (2004). Response of ocean ecosystems to climate warming. Glob. Biogeochem. Cycles 18:GB3003. doi: 10.1029/2003GB002134

Signorini, S. R., Franz, B. A., and McClain, C. R. (2015). Chlorophyll variability in the oligotrophic gyres: mechanisms, seasonality and trends. Front. Mar. Sci. 2:1. doi: 10.3389/fmars.2015.00001

Volpe, G., Nardelli, B. B., Cipollini, P., Santoleri, R., and Robinson, I. S. (2012) Seasonal to interannual phytoplankton response to physical processes in the Mediterranean Sea from satellite observations. Remote Sens. Environ. 117, 223-235. doi: 10.1016/j.rse.2011.09.020

Zingone, A., Phlips, E. J., and Harrison, P. J. (2010). Multiscale variability of twenty-two coastal phytoplankton time series: a global scale comparison. Estuaries Coasts 33, 224-229. doi: 10.1007/s12237-009-9261-x

Conflict of Interest Statement: The authors declare that the research was conducted in the absence of any commercial or financial relationships that could be construed as a potential conflict of interest.

Copyright (c) 2017 Agusti, Martinez-Ayala, Regaudie-de-Gioux and Duarte. This is an open-access article distributed under the terms of the Creative Commons Attribution License (CC BY). The use, distribution or reproduction in other forums is permitted, provided the original author(s) or licensor are credited and that the original publication in this journal is cited, in accordance with accepted academic practice. No use, distribution or reproduction is permitted which does not comply with these terms. 